\title{
THE EFFECTIVENESS OF PRESCRIBED DIET AND EXERCISE ON SERUM GLUCOSE LEVEL OF PATIENT WITH BORDER LINE DIABETES MELLITUS
}

*Ms. J. Victoria Jayarani \& **Dr. Prof. M. Thamilarasa

Diabetes is an “ice-berg" disease (2005).

\section{INTRODUCTION}

Diabetes is a disorder of carbohydrates metabolism caused by combination of hereditary and environmental factors. Diabetes is categorized as Type I or Type II, based on the underlying physiological problem. More than $90 \%$ of all people people with diabetes have this type which develops because of insulin resistance, in which the body is unable to use insulin properly combined with a relative insulin deficiency. The risk of developing type II diabetes increases with age, obesity, and lack of physical activity.

Recent estimates from the World Health Organization predict that if Current trends continue, the number of people with diabetes will more than double, from 176 to 370 million people by 2030. The increase in incidence of diabetes in developing countries follows the trend of urbanization and life style changes, perhaps most importantly a "western style" diet, among Indians every fourth Indian is a diabetic and every second Indian is threatened by it.

\section{STATEMENT OF THE PROBLEM}

"A study to assess the effectiveness of prescribed diet and exercise on serum glucose level of patients with borderline diabetes mellitus, attending the outpatient department of diabetic centres in Chennai"

\section{OBJECTIVES OF THE STUDY}

To compare the pre and post blood sugar level of control group.
To compare the pre and post blood sugar level of experimental group.

To assess the compliance of the patients to prescribed diet and exercise of control and experimental group.

To compare the relationship between demographic variables and the treatment compliance (Diet and Exercise).

\section{RESEARCH METHODOLOGY}

Research approach: Research design selected to achieve the objectives of the study was Quasi experimental using an experimental and control group. The study Design can be schematically represented as follows:

\begin{tabular}{|l|c|c|c|}
\hline $\begin{array}{l}\text { EXPERIMENTAL } \\
\text { GROUP }\end{array}$ & 01 & X & O2 \\
\hline CONTROL GROUP & 01 & -- & 02 \\
\hline
\end{tabular}

\section{THE TOOL DESCRIPTION}

PART - 1: Interview schedule on demographic data- Age, Sex, Educational status, Occupation and if any of the family member having diabetes.

PART - 2: Blood Test- Both the control and experimental group patient's blood was checked for serum glucose level by prick method using Glucometer.

PART - 3: Self monitoring record - The patients were instructed to record their treatment compliance of diet and exercise every day in the self monitoring record for 14 days. 


\section{SCORING KEY}

A 2 point Likert scale was used to assess the treatment compliance (diet and exercise).The patients who recorded less than 4 days of compliance out of 14 days were grouped in no compliance, those who recorded 5-9 days of compliance out of 14 days were grouped in partial compliance and those who had 10-14 days of compliance were grouped in full compliance. And the scoring was given as:

$\begin{array}{ll}\text { No compliance } & --0 \\ \text { Partial compliance } & --1 \\ \text { Full compliance } & --2\end{array}$

\section{DATA COLLECTION PROCEDURE:}

The study was conducted in the outpatient departments of C.S.I Rainy hospital and Venkateswara hospital - Chennai. The data collection period was 4 weeks. The investigator utilized the convenient sampling technique to select the subjects.

\section{RESULTS}

The study findings reveal that compliance with the prescribed diet and exercise seems to be the most effective way in control of serum glucose level in the experimental group patients when comparing with the control group patients.

Assessing the compliance of the patients to prescribed diet and exercise of control and experimental group the overall percentage of control group is inadequate both in diet and exercise compliance where as the experimental has adequate compliance.

On the whole the study results revealed that there is a significant difference in the pre and post test serum glucose values between the control and experimental group. And the study also revealed when a patient with diabetes, comply with their treatment regimen that is advised to them every day have the serum glucose level under control to near normal and can have expected quality life without complications over the years .

And the big challenge we are facing now is to try to implement these findings in our society or among high-risk patients, taking into consideration the great difficulties involved in changing lifestyle and motivation for the compliance and emphasis on the need to understand why diet and exercise are so important in their life.

\section{REFERENCES}

Dhiren Gala et al (2005). Diabetes High Blood Pressure without any Fear. Mumbai: Navaneet publishers.P:62.

Park JE (2005). Text Book of Preventive and Social Medicine. 18th Edition. Jabalpur: Banarsidas Bhanot Publishers: P; 312.

Jean D. Wilson (2004). Endocrinology. 14th edition. Philadelphia: Lippincott: P: 697.

De Feop et al (2006). Exercise and diabetes, Acta Biomed Ateneo Paramense., Vol. 1 (77): P: 14-17.

Darey B Carr et al (2005), A Reduced Fat Diet, Aerobic Exercise in Japnese Americans with impaired glucose tolerance decreases intra abdominal fat and improves insulin sensitivity but not Beta function. Diabetes, Vol. 54, (2) : P: 340- 347. 